\title{
Does the perceived healthcare quality provided by full-time government employee doctors in the public system differ from the perceived care quality in their own privately managed facilities in Nigeria?
}

\author{
Bartholomew S. Eze*1, Mari Jones² \\ ${ }^{1}$ Department of Health Administration and Management, Faculty of Health Sciences and Technology, University of Nigeria, \\ Enugu Campus, Nigeria \\ ${ }^{2}$ Swansea Center for Health Economics, Swansea University, United Kingdom
}

Received: July 25, 2021

DOI: $10.5430 /$ jha.v10n6p1
Accepted: November 15, $2021 \quad$ Online Published: January 10, 2022

URL: https://doi.org/10.5430/jha.v10n6p1

\begin{abstract}
Objective: Although the differences in the quality levels between the public and private sectors have been identified in literature not much is known about the level of quality differences that exist when full-time government employee doctors offer the same clinical services in their own privately managed facilities. The objective of this study was to compare service user perceived quality of care provided by full-time government employee doctors in the public system and in their own privately managed facilities in Nigeria.

Methods: A cross-sectional multistage sampling design was used to elicit service user views on process, structure and outcome elements of quality identified in the Donabedian's care quality model. The software for population surveys in EPI Info 7 was used to calculate the required sample. A total of 407 questionnaires were administered and completed after a pre-test.

Results: Respondents reported better health outcomes in private practice than in the public system and a majority would recommend visiting a dual physician's private practice than the public system where they work full-time. Process aspects of quality, including better rapport with doctors, greater perceived confidentiality, shorter wait times, and absence of bureaucratic impediments were said to be better in privately managed facilities of government doctors. However, respondents said that the public sector was superior in respect of the structure element of quality as reflected in better infrastructure, equipment, and availability of drugs.

Conclusions: Despite the relatively lower cost of care in government hospitals the outcome and process elements are still crucial in determining which sector patients prefer. These two elements seem to have influenced patronage for private practices of dual practitioners.
\end{abstract}

Key Words: Healthcare quality, Dual practice, Nigeria, Public sector, Private practice, Donabedian model

\footnotetext{
*Correspondence: Bartholomew S. Eze; Email: bartholomew.eze@ unn.edu.ng; Address: Department of Health Administration and Management, Faculty of Health Sciences and Technology, University of Nigeria, Enugu Campus, Nigeria. 


\section{INTRODUCTION}

Dual practice (DP) refers to a simultaneous engagement in public and private medical practice by healthcare professionals, particularly medical doctors for remuneration. ${ }^{[1-4]}$ One of the major arguments against DP is that it compromises quality healthcare in the public system, ${ }^{[5-7]}$ especially where there are weak regulatory mechanisms to control the practice.

DP is permitted in Nigeria public system by the Code of Medical practice. ${ }^{[8]}$ The Code allows medical and dental surgeons in full-time public sector employment to use their off-duty hours to do private practice for remuneration. The Code declares it unethical for a registered practitioner in full-time public employment to offer inpatient care in their private practice other than in their employing hospital. But evidence shows that many full-time public sector doctors in Nigeria spend good part of their primary work time in their private practice. ${ }^{[9]}$ Therefore, understanding quality care difference in private practice and the public system from the perspective of the service user is of interest in this study.

Healthcare quality has different meanings depending on the area of interest, ${ }^{[10]}$ however, these authors stressed on the potential value of relying on patients' experience-based narratives that identify what matters to them. It refers to indicators such as proper treatment, interventions, equitable, consistent and timely response. ${ }^{[11]}$ Using outcome as an overall indicator of quality, the Institute of Medicine (IOM) final test of quality of a healthcare system is its ability to help the people it is designed for. ${ }^{[12]}$ There seems to be no consensus on what constitutes quality in healthcare. However, patients are well placed to comment on the services received from a provider. They can judge if provider A met their expectations better than provider B and even if they lack the expert knowledge to judge the technical adequacy of treatment, their perceptions are likely to influence their future behaviour. Thus, it is argued that quality of healthcare has meaning when applied at the individual level only insofar as the individual is the recipient of care. ${ }^{[13,14]}$

Quality can be divided into technical and functional aspects. Technical quality refers to accuracy and procedure, which basically encompasses the competency of staff and their compliance with guidelines on service delivery. ${ }^{[12,15,16]}$ For example, absence of mortality, morbidity, and perioperative complications could be likened to technical quality ${ }^{[17]}$ but this may be difficult for a service user without medical background to judge a provider's performance. Therefore, quality of technical care from the standpoint of the consumer should not be what is done (process), but what is accomplished in terms of final product (outcomes). ${ }^{[14]}$

The functional aspect of quality refers to the "how" or "pro- cess" by which services are delivered to service users. A service user experience of provider's interactions from the time admitted in a healthcare facility until discharge is a good example of functional quality. The subjective nature of functional quality could lend it to different interpretations and thus, difficult to measure and standardise. ${ }^{[15,17]}$ It is noted that service users will often pay more attention to factors such as physician reputation, availability of equipment such as a Magnetic Resonance Imaging (MRI) scanner, building aesthetics, food served and attitude of staff, than to clinical effectiveness in terms of quantified treatment outcomes. ${ }^{[18]}$ Thus, service users may perceive quality in different ways and at different levels. Therefore, the experience about care seems easier to understand for patients than technical measures, which they may lack the expertise to assess. ${ }^{[17]}$

A variety of indicators or constructs have been utilised to measure quality. ${ }^{[19-21]}$ It has not been established which of these measures is more superior to the other, but the key component in all of them is that the patient perspective in their episode of care experience is well captured.

However, the Donabedian quality assessment measure, which comprises the components of structure, process and outcome, seems to be one of the most widely used frameworks. ${ }^{[13,22]}$ Structure describes the physical attributes where care takes place. This includes material resources such as buildings, equipment, human resources, which include personnel (number and qualification of personnel) and organizational structure (medical staff). Process measures describe what is actually done in the process of receiving care. This covers investigations, diagnoses and treatments, with particular attention to the nature of interactions between users and healthcare providers. ${ }^{[23]}$ Here, perceptions of how far care is seen as accessible, convenient, comfortable and timely will depend on patient expectations. ${ }^{[14]}$ Outcome is the effect of care on patients' health status; it is specifically, the consequence of care. This suggests that patient expectation is to recover from treatment received.

These three components can be considered together to reach an overall quality assessment, and performance in one domain can affect the functionality of the others. For example, the existence of good structure may help ensure a good process, which may result in better outcomes. However, the combination of these elements will be dependent on the wider context and are unlikely to be linear. ${ }^{[13]}$ According to these authors, there is no firm causal link and good care can have bad outcomes - there are risks.

Although both process and outcome measures could be considered important for quality assessment, the activities that constitute process are more visible and amenable to measure- 
ment. ${ }^{[13]}$ But definitive clinical outcomes may be difficult to assess and arguably are incomplete as measures of quality of care because they do not capture patient experience. Notwithstanding, Donabedian has argued that a well-rounded assessment of quality should include the three elements. ${ }^{[23]}$ His approach retains an important role for consumers in quality assessment — such assessment should be anchored on patient judgements.

\subsection{Dual practice and healthcare quality}

Although there is limited literature that compares quality of care in the public sector with that of private practice by public sector doctors, available evidence shows that when providers offer the same services in both public and private facilities where they have financial interest, there is an incentive to offer low quality service in the public sector. ${ }^{[6]}$ The declining quality of care in the public healthcare is often attributed to a decreased personal availability of public doctors who are spending much of their time in other income generating activities as a coping mechanism. ${ }^{[5,24-26]}$

Critics often point to a conflict of interest that leads dual practice doctors to lower the quality of their public healthcare services as a way of luring patients to their private practice. For example, evidence from Peru shows that private practice widens the quality gap between public and private sectors. ${ }^{[27]}$ These authors found that DP physicians opted for simple surgical procedures in the public hospital, rather than time-consuming operations producing better outcomes, so as to free more time for lucrative work in their private clinics. Other studies report similar finding that DP sometimes compromises quality of care in the public sector. ${ }^{[7,28]}$ However, poor quality care in the public system could be influenced by other factors such as poor facilities and equipment. ${ }^{[29]}$

There is some evidence that private hospitals perform better than public hospitals regarding good treatment and satisfaction ${ }^{[30-32]}$ but these arguments are not conclusive as other studies have found better satisfaction in the public sector than private. ${ }^{[33-36]}$ With respect to technical quality the public sector is generally perceived as doing better, ${ }^{[33,36,37]}$ whilst in other instance, the public has been criticised for poor equipment ${ }^{[38,39]}$ and medicine supplies. ${ }^{[40,41]}$ In some instances, the public seems to have outperformed the private $^{[33,42]}$ whilst the private may be preferred for other reasons. For instance, the major determinants of preference for government-owned facilities in Nigeria were mainly due to low cost and effective care whilst short-wait time and good staff attitude influenced users' preference for private facilities. ${ }^{[30,43]}$ Overall, evidence has shown that the growth of private medicine is not related to improvement in performance so the conclusion on their performance is diverse. ${ }^{[42]}$

Published by Sciedu Press
However, there is still dearth of information on the actual difference in care quality in the public system and private practices of government doctors.

The primary concern in this paper is how Nigerian service users perceive quality and how far this shapes their decisions about using private care provided by dual practice doctors. The objective of this study was to compare service user perceived quality of care provided by full-time government employee doctors in the public system and in their own privately managed facilities in Nigeria. No studies of this kind have previously been undertaken in Nigeria. Comparative studies on public and private facilities in developing country context including Nigeria ${ }^{[35,44-46]}$ have rarely touched on the influence of dual practice of medical professionals on care quality variations in the public system and private practices. This study is an attempt to address such gap. The information from this study is useful for policy makers and hospital administrators in Nigeria and indeed other countries where dual practice operates.

\section{Methodology}

This paper presents results from a household survey (HHS) completed as one component of larger mixed-methods study.

\subsection{Sample and sample size}

The required sample size was calculated using EPI Info 7. The parameters used for the calculation were the population of Enugu South Local Government Area based on the projected 259,000 population by $2015,{ }^{[47]}$ power of $80 \%$, confidence limit of $95 \%$, and expected frequency of $50 \%$. This suggested that a sample of 384 was required. A pre-test of the questionnaire was conducted with 20 respondents, who were not included in the final questionnaire study. To allow for contingencies a total of 407 valid questionnaires were then completed.

While this study acknowledges the importance of use of validated tools to assess service user perception of healthcare quality, however, the authors did not find any specific relevant validated instrument suitable for this study. Currently, in Nigeria or elsewhere, there is no relevant validated instrument that specifically compares how the perceived healthcare quality provided by full-time government employee doctors in the public system differs from the perceived care quality in their own privately managed facilities. A realistic alternative was to construct a questionnaire that captures the relevant items that are of interest in the study. The questionnaire was administered by a single researcher to minimise misunderstanding of questions or variation in the recording of answers. Data on the socio-demographic characteristics of respondents were obtained as well as information on hospital 
visit experience in both practice types. Generally, the respondent was the senior household member present when the researcher arrived to administer the questionnaire. Respondents were guided through the instrument as the researcher asked the questions and filled in their preferred responses. All methods were performed in accordance with the relevant guidelines and regulations approved by the research ethics committees. The questionnaire was constructed by the researcher to reflect the study objectives and was reviewed by the research team to ensure validity. Regarding the care quality elements, the questionnaire incorporated the Donabedian quality model using five-point Likert scales to compare respondents' assessments of the quality of healthcare rendered by the dual practice doctor in the public system and in their private practice. Data were collected between late January and end of July 2017.

\subsection{Sampling procedure and data gathering}

Data collection procedure involves a household survey intended to explain the views of a sample of service users and their families. All the selected households included a member who had first visited a public hospital in the previous 12 months of the study and then gone to private. The sample was gathered using cross-sectional, multistage sampling. Simple random sampling, systematic sampling and consecutive sampling were utilised at different stages. One local government area (LGA) was randomly selected from the three LGAs that make up the Enugu Urban area. The selected LGA comprises five residential areas from which two areas were randomly selected for questionnaire administration. A list of eligible streets within the selected residential areas was compiled and four streets from each were picked randomly. At that stage, systematic random sampling was used to select houses for questionnaire administration using even or odd numbers. Having selected households, the researcher recruited survey respondents in sequence, based on whether they met the criterion of having visited a public hospital and then gone to private one in the last 12 months, until the required number of household respondents was achieved. Where a building visited was home to more than one household, consecutive sampling was used to administer the questionnaire to other eligible households occupying the building before moving into the next sampled building. Households with any type of health insurance coverage were excluded.

\subsection{Ethics approval and consent to participate}

This study adhered to the usual safeguards employed in research on human subjects. A written informed consent was obtained from all participants prior to the completion of questionnaire. Ethical approvals for this study were obtained from University of Nigeria Teaching Hospital Committee on Med- ical and Scientific Research (Ref: NHREC/05/01/2008BFWA-00002458-IRB00002323), Enugu State Ministry of Health (Ref: MH/MSD/EC/0181), and Swansea University (Ref: 3280415).

\subsection{Analysis of data}

Frequency tables and percentages were generated to represent the socio-demographic characteristics of respondents. A simple descriptive analysis of the Likert means (and 95\% confidence interval) was performed in SPSS statistics v26 software to measure strength of agreement or disagreement. Consequently, Arithmetic means (and 95\% confidence intervals) are shown in all the tables that follow and are used as a simple way of presenting the strength of agreement or disagreement across the five-point Likert scale to allow comparison of the weight of agreement/disagreement between different items in a table. As is usual a numerical value was attached to each of the five items ( 1 = Strongly Disagree, $2=$ Disagree, $3=$ Don't Know, $4=$ Agree, $5=$ Strongly Agree), and an average was calculated. Thus, a mean value below 3 indicates that the weight of opinion disagrees with a statement, whilst one above 3 indicates the weight of opinion agrees, with agreement becoming stronger as the figure rises. It should be noted that there are differences of opinion in the literature regarding the validity of using the mean to analyse Likert data. Critics believe that the transformation of categories such as "strongly agree" and "agree" into ordinal data by attaching numbers to them, does not thereby establish that the intervals between the observed values are equal and constant. They argue that use of the arithmetic mean assumes interval data, and that it is more appropriate to use the mode as the average measure with ordinal Likert data. Typically, however, in real world analysis the mean and mode produce very similar results, so that the mean is used here. Readers who prefer the mode can readily calculate this from the number counts in the Tables below. In the present study relative weight is only of interest when comparison of the importance of different factors is relevant. Even here it may be more important to identify a cluster of relevant factors rather than to place them in precise rank order, so the author feels that a simple descriptive analysis is adequate.

In order to facilitate a clear presentation of results the discussion after each table generally differentiated only between agreement or disagreement (for example, aggregating the "strongly agree" and "agree categories") to give a picture of how respondents as a whole viewed particular questionnaire statements. However, there will be examples where the relative numbers of respondents opting for "strongly agree" as opposed to "agree" do affect the overall weight of opinion, and the analysis used the mean data to examine this if it 
appears important.

\section{Results}

Table 1 shows that 129 males $(31.7 \%)$ and 278 females $(68.3 \%)$ responded to the questionnaire. In terms of the age group of respondents, $59.7 \%$ were from the 18-38 age group, whilst $32.2 \%$ came from the $39-59$ age group, and $7.6 \%$ fell into the $60-80$ age group. There were only two respondents over 80 . Regarding the educational level of respondents, $10.2 \%$ had primary education, whilst the highest number of respondents $(42.6 \%)$ studied up to senior secondary education level. Those who completed a higher and ordinary education diploma or bachelor's degree were $38.9 \%$ and $2.5 \%$ had progressed to a master's degree qualification. A majority of the respondents $(77.6 \%)$ were currently married. The largest group (46.9\%) were self-employed persons, followed by employed artisans (17.9\%) and others working in the private sector $(11.8 \%)$.

Table 2 presents a simple comparison of respondents' assessments of the structure element of healthcare quality between public and private practice provided by the government doctor. This dimension was explored by a group of questions concerned with the physical attributes of care.

By summing the views of respondents who "agreed" and "strongly agreed" on the question items we can see that an overwhelming majority $(94.6 \%)$ of respondents believed that government hospitals have better physical infrastructure (Item 34a). A similar trend was observed in equipment availability where $84.2 \%$ reported better availability of equipment in the public system (Item 34b). Drug availability was another area where over half of the respondents (59.3\%) hold the view that the public system performs better (Item 34e). A majority of respondents believed there were generally fewer qualified healthcare staff in private practice with $77.9 \%$ agreeing with this statement (Item 34c). Most respondents (71.9\%) believed that private facilities had better opening and closing times (Item 34d).

There is a general view that the physical infrastructure of the public system is superior to that in private practice. Building a hospital is a major capital project that, except for a few well-financed private ventures, only the Government can afford. Many dual practitioners use rented houses or flats in apartment blocks to open clinics and even small hospitals. Similarly, the Government is better able to afford costly medical equipment, with the purchase cost and maintenance of the latest high-technology medical equipment out of reach of most individual doctors.

Table 3 compares the process element of healthcare quality in DPs' public and private practices. It measures respondents' perceptions of what is done in the process of receiving care in both places of practice.

Table 1. Socio-demographic characteristics of respondents $(\mathrm{N}=407)$

\begin{tabular}{|c|c|c|}
\hline Variable & $\mathbf{N}(\%)$ & Summary statistic \\
\hline \multicolumn{3}{|l|}{ Sex } \\
\hline Male & $129(31.7)$ & \multirow{6}{*}{$\begin{array}{l}\text { Mean age }=38.72 \\
\text { Range }=19-86 \\
\text { Standard error }=2.35\end{array}$} \\
\hline Female & $278(68.3)$ & \\
\hline \multicolumn{3}{|l|}{ Age group } \\
\hline $18-38$ & $243(59.7)$ & \\
\hline $39-59$ & $131(32.2)$ & \\
\hline $60-80$ & $31(7.6)$ & \\
\hline Over 80 & $2(0.5)$ & \\
\hline \multicolumn{3}{|l|}{ Highest Edu. level } \\
\hline Primary school & $41(10.2)$ & \\
\hline Junior secondary & $7(1.7)$ & \\
\hline Senior secondary & $171(42.6)$ & \\
\hline Ordinary Nat. Dip & $34(8.5)$ & \\
\hline Higher Nat. Dip & $51(12.7)$ & \\
\hline Bachelor of Science & $71(17.7)$ & \\
\hline Master of Science & $10(2.5)$ & \\
\hline Other & $16(4.0)$ & \\
\hline \multicolumn{3}{|l|}{ Marital status } \\
\hline Currently married & $316(77.6)$ & \\
\hline Single & $68(16.7)$ & \\
\hline Separated & $2(0.5)$ & \\
\hline Widowed & $21(5.2)$ & \\
\hline \multicolumn{3}{|l|}{ Occupation } \\
\hline Govt worker & $30(7.4)$ & \\
\hline Employed in priv. sector & $48(11.8)$ & \\
\hline Self-employed & 191(46.9) & \\
\hline Artisan & $73(17.9)$ & \\
\hline Student & $12(2.9)$ & \\
\hline Unemployed & $36(8.8)$ & \\
\hline Other & $17(4.2)$ & \\
\hline
\end{tabular}

Again, for the purposes of analysis the percentages of "agree" and "strongly agree" were combined to obtain a simple agreement in each question statement. Most respondents (87\%) reported having a better rapport with their doctor in private practice (Item 341). Private practices are usually smaller in nature, and it may be easier to build rapport with a reduced number of patients. There is also a majority perception (86.1\% of respondents) that doctors in private practice are better at explaining things in a way patient can understand (Item 34k). Only small minorities of respondents agreed with the statements that there is more time to discuss patients' medical problems in government hospitals (15.5\%) or that government doctors take more time to listen carefully to 
patients $(16.7 \%)$ (Items $34 \mathrm{~g}$ and $34 \mathrm{j}$ ), which suggests that private practice is seen to give more time for patients. Similarly, only $26 \%$ of respondents agreed with the notion that waiting times are shorter in the public sector (Item 34f). Although confidentiality is a patient right, the public system was seen as likely to compromise this by $60.7 \%$ of respondents (Item 34i). Courtesy and respect accorded to patients were per- ceived to be higher in private practice with $59.1 \%$ agreeing that this was the case (Item 34h). Taken together these responses suggest that patients believe that paying for private care translates into a better doctor-patient relationship, with improved rapport and more time available to discuss patient concerns.

Table 2. Compares structure element of healthcare quality between DPs' private practice and public practice $(\mathrm{N}=407)$

\begin{tabular}{|c|c|c|c|c|c|c|c|}
\hline Question & $\begin{array}{l}\text { Strongly } \\
\text { disagree } \\
n(\%)\end{array}$ & $\begin{array}{l}\text { Disagree } \\
\mathbf{n}(\%)\end{array}$ & $\begin{array}{l}\text { Don't } \\
\text { know n(\%) }\end{array}$ & $\begin{array}{l}\text { Agree } \\
\mathbf{n}(\%)\end{array}$ & $\begin{array}{l}\text { Strongly } \\
\text { agree } n(\%)\end{array}$ & Mean $[S D]$ & $\begin{array}{l}95 \% \text { CI } \\
\text { (lower-upper) }\end{array}$ \\
\hline $\begin{array}{l}\text { 34a). Better physical infrastructure } \\
\text { (buildings) exists in public hospitals } \\
\text { than in private practices set up by } \\
\text { government doctors }\end{array}$ & $2(0.5)$ & $18(4.4)$ & $2(0.5)$ & $157(38.6)$ & $228(56.0)$ & $4.5(0.8)$ & $4.4-4.5$ \\
\hline $\begin{array}{l}34 \mathrm{~b}) \text {. There is better availability of } \\
\text { equipment in public hospitals than in } \\
\text { private practices of government } \\
\text { doctors }\end{array}$ & $15(3.7)$ & $46(11.3)$ & $3(0.7)$ & $178(43.7)$ & $165(40.5)$ & $4.1(1.0)$ & $4.0-4.2$ \\
\hline $\begin{array}{l}\text { 34c). There are fewer qualified health } \\
\text { care staff in private practices of } \\
\text { government doctors compared with } \\
\text { public facilities }\end{array}$ & $26(6.4)$ & $55(13.5)$ & $9(2.2)$ & $174(42.8)$ & $143(35.1)$ & $3.9(1.2)$ & $3.7-4.0$ \\
\hline $\begin{array}{l}34 \mathrm{~d}) \text {. Government doctors engaged in } \\
\text { private practice have better opening } \\
\text { and closing hours than public hospitals }\end{array}$ & $15(3.7)$ & $73(18.0)$ & $26(6.4)$ & $172(42.5)$ & $119(29.4)$ & $3.8(1.2)$ & $3.7-3.9$ \\
\hline $\begin{array}{l}34 \mathrm{e}) \text {. There is better availability of } \\
\text { drugs in private practice of } \\
\text { government doctors than in } \\
\text { government hospitals }\end{array}$ & $112(27.8)$ & $127(31.5)$ & $23(5.7)$ & $81(20.1)$ & $60(14.9)$ & $2.6(1.5)$ & $2.5-2.8$ \\
\hline
\end{tabular}

Table 4 shows how respondents rated the outcome element of healthcare quality obtained in the two practice sites.

In general, most patients believed that private facilities delivered better clinical outcomes. Only $31.2 \%$ of respondents believed that the recovery rate was higher in public hospitals (Item 34o). Likewise, in respect of health status improvement, only $23.3 \%$ believed this was greater when treated in the public system (Item $34 \mathrm{p}$ ). This may be related to overall satisfaction with the service, with only $28.3 \%$ saying that they were more satisfied with treatment in public facilities $(34 \mathrm{~m})$. Most respondents $(78.1 \%)$ agreed that doctors in private practice gave better explanations of their illness condition and treatment options (Item 34n). In line with the above, an overwhelming majority of the respondents would recommend visiting private practice rather than public facilities where these doctors work, with $80.3 \%$ agreeing (Item $34 q)$.
The outcome questions suggest that small number of patients think that outcomes are better in the public sector. The finding that around $28 \%$ are more satisfied with treatment in that sector suggests that other factors such as cost enter the picture. It is unclear whether perceptions that recovery rates are better, or health status improves more following private treatment rests on an informed assessment of clinical outcomes, but overall, it seems clear that private practice is preferred to the public system in terms of the outcome element of quality.

\section{Discussion}

Generally, government hospitals were perceived as having better infrastructure, equipment, and drug availability than private facilities. ${ }^{[33,36]}$ Most government facilities are housed in substantial permanent buildings in accessible locations. Some smaller private practices are set up in rented flats in residential buildings, and the physical setting can be less than 
ideal. Items such as oxygen cylinder, suction machine or defibrillator may be missing in the treatment room. Although there are often also equipment deficiencies in government hospitals, high-level hospitals will normally have medical equipment of this kind. However, regarding this some senior dual practice physicians may have better equipment in their facilities than the lower-level public hospitals. Whilst some authors believe that government hospitals have better equipment, ${ }^{[33]}$ others hold the reverse view. ${ }^{[38,39]}$ The area where clear differences do emerge is the public tertiary hospitals and specialist centres, which clearly do have more sophisticated equipment than even the larger private practice doctor-owned hospitals.

Table 3. Compares process element of healthcare quality between DP's private practice and public practice

\begin{tabular}{|c|c|c|c|c|c|c|c|}
\hline Question & $\begin{array}{l}\text { Strongly } \\
\text { disagree } \\
\mathbf{n}(\%)\end{array}$ & $\begin{array}{l}\text { Disagree } \\
\mathbf{n}(\%)\end{array}$ & $\begin{array}{l}\text { Don't know } \\
\text { n(\%) }\end{array}$ & $\begin{array}{l}\text { Agree } \\
\mathbf{n}(\%)\end{array}$ & $\begin{array}{l}\text { Strongly agree } \\
\mathbf{n}(\%)\end{array}$ & Mean $[S D]$ & $\begin{array}{l}95 \% \text { CI } \\
\text { (lower-upper) }\end{array}$ \\
\hline $\begin{array}{l}34 \mathrm{f}) \text {. The waiting time to see a } \\
\text { doctor in public hospitals is less } \\
\text { than the waiting time to see him in } \\
\text { his private practice }\end{array}$ & $108(26.5)$ & $178(43.7)$ & $15(3.7)$ & $53(13.0)$ & $53(13.0)$ & $2.4(1.4)$ & $2.3-2.6$ \\
\hline $\begin{array}{l}34 \mathrm{~g} .) \text { There is more time to discuss } \\
\text { my medical problem with a } \\
\text { government doctor in public } \\
\text { hospital than in private practice }\end{array}$ & $106(26.0)$ & $220(54.1)$ & $18(4.4)$ & $33(8.1)$ & $30(7.4)$ & $2.2(1.1)$ & $2.1-2.3$ \\
\hline $\begin{array}{l}34 \mathrm{~h}) \text {. Patients are not treated with } \\
\text { courtesy and respect by } \\
\text { government doctors in public } \\
\text { hospitals compared with private } \\
\text { practices }\end{array}$ & $14(3.5)$ & $76(18.8)$ & $34(8.4)$ & $154(38.0)$ & $127(31.4)$ & $3.7(1.2)$ & $3.6-3.9$ \\
\hline $\begin{array}{l}\text { 34i). Patient confidentiality is not } \\
\text { taken seriously by government } \\
\text { doctors in public hospitals } \\
\text { compared with private practices }\end{array}$ & $24(5.9)$ & $77(19.0)$ & $58(14.3)$ & $145(35.8)$ & $101(24.9)$ & $3.6(1.2)$ & $3.4-3.7$ \\
\hline $\begin{array}{l}34 \mathrm{j}) \text {. Doctors in public hospitals } \\
\text { take more time to listen carefully } \\
\text { to patients than in private practices }\end{array}$ & $108(26.6)$ & $213(52.5)$ & $17(4.2)$ & $33(8.1)$ & $35(8.6)$ & $2.2(1.2)$ & $2.1-2.3$ \\
\hline $\begin{array}{l}34 \mathrm{k}) \text {. Government doctors whilst } \\
\text { in their private practices take their } \\
\text { time to explain things in a way I } \\
\text { could understand compared with } \\
\text { when they are in public hospitals }\end{array}$ & $10(2.5)$ & $40(9.9)$ & $6(1.5)$ & $185(45.8)$ & $163(40.3)$ & $4.1(1.0)$ & $4.0-4.2$ \\
\hline $\begin{array}{l}\text { 34l). I have a rapport with my } \\
\text { doctor in his private practice } \\
\text { compared with when I visit him in } \\
\text { the government hospital }\end{array}$ & $8(2.0)$ & $39(9.6)$ & $6(1.5)$ & 157(38.6) & 197(48.4) & $4.2(1.0)$ & $4.1-4.3$ \\
\hline
\end{tabular}

Note. Source: research data

Even though drug availability is generally better in public hospitals than in private practices, as suggested in this study, the overall picture is far from straightforward. The drug supply chain in government hospitals may be bureaucratized, leading to periodic shortages and delays in availability. ${ }^{[40,41]}$ In contrast, the private sector is less affected by administrative hiccups and so may have better drugs supplies at certain times. ${ }^{[46]}$ Often, the dual practitioner can ask for a supply of drugs from their pharmaceutical representatives at any time needed with minimal delay, or buys from the open market, which may be risky due to fake drugs.
The private sector offers extended business hours, but usually fewer qualified healthcare staff. Private practitioners compete for business by providing flexible access at convenient times. This practice of extending business hours could mean serving more clients in need by bringing care closer to the people. ${ }^{[35]}$ Public hospitals are run as civil service organizations with a normal outpatient department closing time of 2.00 p.m., meaning that patients visiting public hospitals later than that can usually only see a doctor via the emergency department. Research suggests that the hours of availability of DP physicians may be greater in their private practice 
than in their public workplace as an attempt to supplement DP doctor time spent away from the public hospital means their public sector income. ${ }^{[24,25]}$ But whilst the extension worse access for patients relying on that service. of business hours may improve access for private patients,

Table 4. Compares outcome element of healthcare quality between DPs private practice and public practice

\begin{tabular}{|c|c|c|c|c|c|c|c|}
\hline Question & $\begin{array}{l}\text { Strongly } \\
\text { disagree } \\
\mathbf{n}(\%) \\
\end{array}$ & $\begin{array}{l}\text { Disagree } \\
\mathbf{n}(\%)\end{array}$ & $\begin{array}{l}\text { Don't know } \\
\text { n(\%) }\end{array}$ & $\begin{array}{l}\text { Agree } \\
\mathbf{n}(\%)\end{array}$ & $\begin{array}{l}\text { Strongly agree } \\
\mathbf{n}(\%)\end{array}$ & Mean $[S D]$ & $\begin{array}{l}95 \% \text { CI } \\
\text { (lower-upper) }\end{array}$ \\
\hline $\begin{array}{l}34 \mathrm{~m}) \text {. I am more satisfied when } \\
\text { treated in a public hospital by } \\
\text { government doctors than when } \\
\text { treated in their private practices }\end{array}$ & $142(34.9)$ & $141(34.6)$ & $9(2.2)$ & $72(17.7)$ & $43(10.6)$ & $2.3(1.4)$ & $2.2-2.5$ \\
\hline $\begin{array}{l}34 \mathrm{n}) \text {. The nature of my illness } \\
\text { condition and the treatment } \\
\text { options open to me are explained } \\
\text { better by the government doctor } \\
\text { in his private practice than in the } \\
\text { public hospital }\end{array}$ & $18(4.4)$ & $63(15.5)$ & $8(2.0)$ & $164(40.3)$ & $154(37.8)$ & $3.9(1.2)$ & $3.8-4.0$ \\
\hline $\begin{array}{l}34 \mathrm{o}) \text { The recovery rate is higher } \\
\text { in public hospitals than in private } \\
\text { practice }\end{array}$ & $64(15.7)$ & $161(39.6)$ & $55(13.5)$ & $86(21.1)$ & $41(10.1)$ & $2.7(1.3)$ & $2.6-2.8$ \\
\hline $\begin{array}{l}34 \mathrm{p}) \text {. My health status improves } \\
\text { more when treated in public } \\
\text { hospital by government doctors } \\
\text { compared with when treated in } \\
\text { their private practices }\end{array}$ & $79(19.6)$ & $202(50.0)$ & $29(7.2)$ & $58(14.4)$ & $36(8.9)$ & $2.4(1.2)$ & $2.3-2.6$ \\
\hline $\begin{array}{l}34 \mathrm{q}) \text {. I would recommend } \\
\text { visiting a government doctor in } \\
\text { his private practice as opposed to } \\
\text { a government hospital }\end{array}$ & $28(6.9)$ & $49(12.1)$ & $3(0.7)$ & $143(35.2)$ & $183(45.1)$ & $4.0(1.2)$ & $3.9-4.1$ \\
\hline
\end{tabular}

Poor staffing in private practice sometimes has a direct effect on clinical quality. To keep labour costs down many DP doctors, employ only a few staff, perhaps in a small office with only a single unqualified nurse. Some clinics may have one trained nurse who doubles as pharmacy attendant and receptionist. The widespread use of unqualified personnel in private facilities is reported to have resulted in poor diagnostic accuracy and sub-optimal medical management. ${ }^{[35]}$ By contrast, the public system insists on proper qualifications and meets all professional licensing requirements. Moreover, public doctors working in a clinical team are subject to near-continuous peer review.

The findings from the process element of quality indicate better rapport with doctors in private practice. ${ }^{[30,32,43]}$ Respondents believed there was a more positive relationship with the doctor in private practice, including in areas such as confidentiality. There is a perception that doctor and patient interact more closely, and that this leads to a better understanding of the patient's needs and to individually customized management. Doctors make care plans and guide patients through the system. In terms of Strong's ${ }^{[48]}$ analysis of the "ceremonial order" of the clinic, DP physicians use the "private" format, which has contrasting qualities to the "bureaucratic" format widely found in public healthcare. There seems to be a difference in the style of selling private medicine compared with providing public medicine. The public system with its larger patient flows, standardized policies and bureaucratic procedures is less responsive to individual preferences and struggles to build the same kind of trust that patients say they have with their private DP physician.

Waiting time to be seen in private practice was believed to be shorter compared with the public system, largely because of the absence of bureaucracy. In private practice, the patient typically goes straight to a consultation with the physician. Given the fact that relatively few can afford private healthcare, there are rarely the type of long queues seen in the public system. The pattern of shorter waiting times in the private compared to the public sector was also reported in an earlier study. ${ }^{[34,35,43]}$ Patients, therefore, may be more satisfied with the process element of quality in private practice 
than they are in the public sector.

Respondents also suggested that private practices run by DP doctors achieve better outcomes than do public hospitals. Health outcomes may be regarded as the effects of healthcare received, but it is unclear whether service users are able to assess the technical quality of the treatments provided. Service users generally regard a quality treatment as one that produces a positive experience during the treatment process, whilst they assume that a negative experience equates to poor quality care. A majority of respondents believed that private practice offers better health outcomes in terms of quicker recovery and improvement in health status.

Past studies show little consensus regarding which sector produces better outcomes, either in terms of measurable clinical outcomes or patient perceptions of quality care. For example, it is reported that outcomes in the public sector were generally superior ${ }^{[33,36]}$ whilst Alumran and colleagues reported a perceived higher level quality of care in the private setting ${ }^{[32]}$ and poor quality outcome in both providers reported by others. ${ }^{[46]}$ The respondents in the present study come down on the side of the private sector providing better outcomes, even though many of them opt to use the public sector for such reasons as cost or the availability of medical equipment and more qualified healthcare personnel. ${ }^{[45]}$ This means that a degree of ambivilance remains, and individual patients may make different judgements according to such factors as the nature of the condition to be treated, affordability of treatment and the ease with which specialist care can be accessed in their local healthcare facilities. One major limitation of this study is that it relied on patient perceptions of healthcare quality. The technical quality of healthcare was not measured directly in the quality assessment, and that could bias the study findings. It would have been very difficult to arrange measurement of technical quality across the diverse range of health conditions presented by the respondent patients. Self-reported outcomes were a pragmatic alternative but introduce a degree of subjectivity linked to personal opinions and different degrees of understanding of medical knowledge. In addition, this study recognises the non-use of a validated tool as a limitation.

\section{Conclusions}

Overall, the survey found that respondents generally regarded private practice as better than public healthcare in respect of both the process and outcome elements of quality, whilst public practice does better in the structure element of quality. Process and outcome factors may well encourage patients to visit the dual practice physician's private facility. Confronted with the bureaucracy of the public system, many opt for the flexibility of the private clinic and DPs are all too willing to provide better healthcare in their private practice. Despite the relatively lower cost of care in government hospitals the outcome and process elements are still crucial in determining which sector patients prefer. Potentially, the demand for the public sector care may be affected whilst creating a market for dual practice physicians. Public system can improve on process and outcome elements of quality to increase patient experience.

\section{ACKNOWLedgements}

We are grateful to the Tertiary Education Trust Fund (TETFUND) for the financial support provided for the first author's doctoral programme.

\section{CONFLICTS OF INTEREST Disclosure}

The authors declare they have no conflicts of interest.

\section{REFERENCES}

[1] Abera GG, Alemayehu YK, Herrin J. Public-on-private dual practice among physicians in public hospitals of Tigray National Regional State, North Ethiopia: perspectives of physicians, patients and managers BMC Health Services Ressearch. 2017; 17(713). PMid: 29126453. https://doi.org/10.1186/s12913-017-2701-6

[2] Ashmore J, Gilson L. Conceptualizing the impacts of dual practice on the retention of public sector specialists - evidence from South Africa. Hum Resour Health. 2015; 13(1): 3. PMid: 25600159. https : //doi.org/10.1186/1478-4491-13-3

[3] Do N, Do YK. Dual practice of public hospital physicians in Vietnam. Health Policy Plan. 2018; 33(8): 898-905. PMid: 30289510. https://doi.org/10.1093/heapol/czy075

[4] Miotto BA, Guilloux AGA, Cassenote AJF, et al. Physician's sociodemographic profile and distribution across public and private health care: an insight into physicians' dual practice in Brazil.
BMC Health Serv Res. 2018; 18(1): 299. PMid: 29688856. https : //doi.org/10.1186/s12913-018-3076-z

[5] McPake B, Russo G, Hipgrave D, et al. Implications of dual practice for universal health coverage. Bull World Health Organ. 2016; 94: 142-6. PMid: 26908963. https ://doi.org/10.2471/BLT . 14.1 51894

[6] Das J, Holla A, Mohpal A. Quality and accountability in health care delivery: Audit-study evidence from primary care in India. American Economic Review. 2016; 106(12): 3765-99. PMid: 29553219. https://doi.org/10.1257/aer. 20151138

[7] Kiwanuka S, Kinengyere A, Nalwadda C, et al. Effects of interventions to manage dual practice. Cochrane Database of Systematic Reviews. 2011; 3. PMid: 21735429. https://doi.org/10.1002/ 14651858. CD008405.pub2

[8] MDCN. The Code of Medical Ethics in Nigeria. Abuja, Nigeria: Medical and Dental Council of Nigeria; 2008. 
[9] Osuagu EM. Ethics and Medico legal Aspects of Medical Practice. Enugu, Nigeria: Jaron Industries Ltd; 2010.

[10] Swinglehurst D, Emmerich N, Maybin J, et al. Rethinking 'quality' in health care. Journal of Health Services Research \& Policy. 2014; 19(2): 65-6. PMid: 24470532. https://doi .org/10.1177/1355 819613518522

[11] Allen-Duck A, Robinson JC, Stewart MW. Healthcare Quality: A Concept Analysis. Nurs Forum. 2017; 52(4): 377-86. PMid: 28407249. https://doi.org/10.1111/nuf.12207

[12] Institute of Medicine. Crossing the quality chasm: A new health system for the 21st century. Washington, DC: National Academy Press; 2001.

[13] Campbell S, Roland M, Buetow S. Defining health care quality. Soc Sci Med. 2000; 51: 1611-25. https://doi.org/10.1016/S027 7-9536(00) 00057-5

[14] Donabedian A. Quality assurance in healthcare: a consumers' role. Quality in HealthCare. 1992; 1: 247-51. PMid: 10136873. https: //doi.org/10.1136/qshc.1.4.247

[15] Donabedian A. Evaluating the Quality of Medical Care. The Milbank Quarterly. 2005; 83(4): 691-729. PMid: 16279964. https: //doi.org/10.1111/j.1468-0009.2005.00397.x

[16] Alhassan RK, Duku SO, Janssens W, et al. Comparison of Perceived and Technical Healthcare Quality in Primary Health Facilities: Implications for a Sustainable National Health Insurance Scheme in Ghana. PLoS One. 2015; 10(10): e0140109. PMid: 26465935. https://doi.org/10.1371/journal.pone. 0140109

[17] Fiala TG. What do patients want? Technical quality versus functional quality: a literature review for plastic surgeons. Aesthet Surg J. 2012; 32(6): 751-9. PMid: 22859547. https://doi.org/10.1177/10 90820X12452555

[18] Royce R. A Study of the dynamics of the private health care market in the United Kingdom with particular reference to the impact of British United Provident Association (BUPA) provider and benefit initiatives. Swansea Swansea University. 2009.

[19] Leonardsen AL, Grøndahl VA, Ghanima W, et al. Evaluating patient experiences in decentralised acute care using the Picker Patient Experience Questionnaire; methodological and clinical findings. BMC Health Serv Res. 2017; 17(1): 685. PMid: 28962561. https://doi .org/10.1186/s12913-017-2614-4

[20] Agarwal A, Singh MR. Service Quality and Patient Satisfaction: An Exploratory Study of Pathology Laboratories in Jaipur. Hosp Top. 2016; 94(2): 23-32. PMid: 27315561. https ://doi.org/10.108 $0 / 00185868.2016 .1146544$

[21] Londoño AMM, Schulz PJ. Impact of patients' judgment skills on asthma self-management: a pilot study. J Public Health Res. 2014; 3(3): 307. PMid: 25553312. https://doi.org/10.4081/jphr .2014 .307

[22] Moore L, Lavoie A, Bourgeois G, et al. Donabedian's structureprocess-outcome quality of care model: Validation in an integrated trauma system. Journal of Trauma and Acute Care Surgery. 2015; 78(6): 1168-75. PMid: 26151519. https://doi.org/10.1097/ TA. 0000000000000663

[23] Donabedian A. The quality of care: how can it be assessed? Arch Pathol Lab Med. 1997; 121: 1743-8. PMid: 3045356. https: //doi.org/10.1001/jama.260.12.1743

[24] Gonzalez P, Montes-Rojas G, Pal S. Dual Practice of Health Workers: Evidence from Indonesia Indonesia. 2018. https ://doi .org/10 $.2139 / \mathrm{ssrn} .3306812$

[25] Akwataghibe N, Samaranayake D, Lemiere C, et al. Assessing health workers' revenues and coping strategies in Nigeria-a mixedmethods study. BMC Health Services Research. 2013; 13(387). PMid: 24093219. https://doi.org/10.1186/1472-6963-13-387
[26] Belita A, Mbindyo P, English M. Absenteeism amongst health workers-developing a typology to support empiric work in lowincome countries and characterizing reported associations. Hum Resour Health. 2013; 11: 34. PMid: 23866770. https ://doi.org/ 10.1186/1478-4491-11-34

[27] LaGrone L, Isquith-Dicker L, Egoavil E, et al. Surgery and trauma care providers' perception of the impact of dual-practice employment on quality of care provided in an Andean country. BJS. 2017; 104(6): 704-9. PMid: 28251600. https ://doi .org/10.1002/bjs. 1047 8

[28] Alaref J, Awwad J, Araujo E, et al. To ban or not to ban? Regulating dual practice in Palestine. Health Systems and Reform. 2017; 3(1): 42-55. PMid: 31514710. https : //doi .org/10.1080/23288604 .2016 .1272980

[29] Hipgrave D, Hort K. Dual practice by doctors working in South and East Asia: A review of its origins, scope and impact, and the options for regulation. Health Policy And Planning. 2013; 54(2): 267-79.

[30] Adebimpe WO, Babatunde S, Asuzu MC. Clients' Perception of and Satisfaction with Quality of Directly Observed Treatment Short Course: A Comparative Study of Private and Public Health Facilities in Southwestern Nigeria. West Afr J Med. 2019; 36(1): 54-60.

[31] Olawoye O, Ashaye A, Bekibele C, et al. A comparative evaluation of patients satisfaction with cataract surgical services in a public tertiary and a private secondary eye care facilities in Nigeria. Ann Afr Med. 2012; 11(3): 157-62. PMid: 22684134. https : //doi.org/10.4103/1596-3519.96877

[32] Alumran A, Almutawa H, Alzain Z, et al. Comparing public and private hospitals' service quality. Journal of Public Health. 2020. https://doi.org/10.1007/s10389-019-01188-9

[33] Rannan-Eliya RP, Wijemanne N, Liyanage IK, et al. Quality of inpatient care in public and private hospitals in Sri Lanka. Health Policy Plan. 2015; 30 Suppl 1: i46-58. PMid: 25759454. https: //doi.org/10.1093/heapol/czu062

[34] Hercos BVS, Berezovsky A. Quality of the ophthalmological service to outpatients of the public and private healthcare systems. Arq Bras Oftalmol. 2017; 80(6): 350-4. PMid: 29267568. https : //doi.org/10.5935/0004-2749.20170086

[35] Basu S, Kishore S, Panjabi R, et al. Comparative performance of private and public health systems in low-and-middle income countries: A systematic review. PLoS Medicine. 2012; 9(6). PMid: 22723748. https://doi.org/10.1371/journal.pmed.1001244

[36] Umeokonkwo CD, Aniebue PN, Onoka CA, et al. Patients satisfaction with HIV and AIDS care in Anambra State, Nigeria. PLoS One. 2018; 13. PMid: 30365560. https ://doi.org/10.1371/journa 1. pone. 0206499

[37] Adesanya T, Gbolahan O, Ghannam O, et al. Exploring the responsiveness of public and private hospitals in lagos, Nigeria. $\mathrm{J}$ Public Health Res. 2012; 1(1): 2-6. PMid: 25170439. https: //doi.org/10.4081/jphr.2012.e2

[38] Okoye MT, Nguyen ET, Kushner AL, et al. Can Economic Performance Predict Pediatric Surgical Capacity in Sub-Saharan Africa? World Journal of Surgery. 2016; 40(6): 1336-43. PMid: 26822156. https://doi.org/10.1007/s00268-016-3410-8

[39] Adekoya BJ, Shah SP, Adepoju FG. Managing glaucoma in Lagos State, Nigeria - availability of Human resources and equipment. Niger Postgrad Med J. 2013; 20(2): 111-5.

[40] Ushie BA, Ugal DB, Ingwu JA. Overdependence on For-Profit Pharmacies: A Descriptive Survey of User Evaluation of Medicines Availability in Public Hospitals in Selected Nigerian States. PLoS One [Internet]. 2016; 11(11): [e0165707 p.]. PMid: 27812177. https://doi.org/10.1371/journal.pone.0165707 
[41] Ogbonna B. National drug distribution in Nigeria; implications for the goals of National Drug Policy. Eutopean Journal For Pharmacy And Medical Research. 2016; 3: 1-4.

[42] Kruse FM, Stadhouders NW, Adang EM, et al. Do private hospitals outperform public hospitals regarding efficiency, accessibility, and quality of care in the European Union? A literature review. Int J Health Plann Manage. 2018; 33(2): e434-e53. PMid: 29498430. https://doi.org/10.1002/hpm.2502

[43] Oredola A, Odusanya O. A survey of the perception of the quality of and preference of healthcare services amongst residents of Abeokuta South Local Government, Ogun State, Nigeria. Nigerian Journal of Clinical Practice. 2017; 20(9): 1088-97. PMid: 29072230. https://doi.org/10.4103/njcp.njcp_228_16

[44] Polsa P, Spens K, Soneye A, et al. Comparing the perceived quality of private and public health services in Nigeria. Journal of Management
Policy and Practice. 2011; 12: 18-26.

[45] Adesanya T, Gbolahan O, Ghannam O, et al. Exploring the Responsiveness of Public and Private Hospitals in Lagos, Nigeria. Journal of Public Health Research. 2012; 1: 2-6. PMid: 25170439. https://doi.org/10.4081/jphr.2012.e2

[46] Berendes S, Heywood P, Oliver S, et al. Quality of Private and Public Ambulatory Health Care in Low and Middle Income Countries: Systematic Review of Comparative Studies. PLOS Medicine. 2011; 8(4): e1000433. PMid: 21532746. https://doi.org/10.1371/ journal.pmed. 1000433

[47] National Population Commission. National Census Abuja, Nigeria: The National Population Commission; 2006.

[48] Strong P. The Ceremonial Order of Clinic. Parents, Doctors and Medical Bureaucracies. London: Routledge and Kegan Paul; 1979. 